\title{
Strategies for achieving viral hepatitis $C$ micro-elimination in the Netherlands
}

\author{
P. A. M. Kracht ${ }^{1 *}$ D, J. E. Arends ${ }^{1}$, K. J. van Erpecum², A. Urbanus ${ }^{3}$, J. A. Willemse ${ }^{4}$, A. I. M. Hoepelman ${ }^{1}$ \\ and E. A. Croes ${ }^{5}$
}

\begin{abstract}
s
The Netherlands is striving to achieve national elimination of the hepatitis $\mathrm{C}$ virus $(\mathrm{HCV})$ as one of the first countries worldwide. The favorable HCV epidemiology with both low prevalence and incidence, together with access to care and treatment, present excellent conditions to further build on towards this objective. The Dutch national plan on viral hepatitis, introduced in 2016, defines targets in the HCV healthcare cascade and provides a structural framework for the development of elimination activities. Since many different stakeholders are involved in HCV care in the Netherlands, focus has been placed on micro-elimination initiatives as a pragmatic and efficient approach. These numerous micro-eliminations projects have brought the Netherlands closer to HCV elimination. In the near future, efforts specifically have to be made in order to optimize case-finding strategies and to successfully accomplish the nationwide implementation of the registration and monitoring system of viral hepatitis monoinfections, before this final goal can be reached. The upcoming years will then elucidate if the Dutch' hands on approach has resulted in sufficient progress against HCV and if the Netherlands will lead the way towards nationwide HCV elimination.
\end{abstract}

Keywords: Hepatitis C virus, Micro-elimination, Hep-CORE, HCV cascade of care

\section{Background}

Global elimination and eradication of the hepatitis $\mathrm{C}$ virus $(\mathrm{HCV})$ has become the ultimate endeavor and final objective ever since the introduction of highly effective direct-acting antivirals (DAAs). The once fatal disease has thus been transformed into an infection that can effortlessly be cured, provided that one has access to care and therapy. Consequently, the World Health Organization (WHO) even envisioned universal elimination of the HCV to be accomplished by the year 2030 [1]. To this end, the WHO urged countries to develop and implement national policies on viral hepatitis. However, the European Liver Patients Association (ELPA) Hep-CORE study revealed that 14/27 countries still did not have a written national plan for the management of hepatitis C and / or hepatitis B (HBV) in 2016. The Netherlands therefore subsequently introduced a

\footnotetext{
* Correspondence: p.a.m.kracht@umcutrecht.nl

${ }^{1}$ Department of Internal medicine and Infectious disease, Utrecht University, University Medical Center Utrecht, Utrecht, the Netherlands

Full list of author information is available at the end of the article
}

national plan on viral hepatitis in 2016 defining targets for each step in the Dutch HCV healthcare cascade: 1) awareness and prevention; 2) testing and diagnosis; 3) linkage to care; 4) access to medication and 5) monitoring and evaluation, in order to eventually achieve $\mathrm{HCV}$ elimination [2]. National coordination of HCV elimination however is complicated by (regional) differences in $\mathrm{HCV}$ patient subpopulations and the high number of stakeholders involved in $\mathrm{HCV}$ care. Considering these diversities, a uniform nationwide strategy targeting all $\mathrm{HCV}$ patients is unlikely to be the key solution to finally eliminate $\mathrm{HCV}$. A more pragmatic approach would be to apply more focus and work towards 'micro-elimination' in different HCV subpopulations (e.g., individuals with HIV or hemophilia, (ever) injection drug users, migrants from high endemic countries, health care workers, prisoners). Micro-elimination, by way of targeting smaller and clearly delineated $\mathrm{HCV}$ risk groups, allows for faster and more efficient delivery of interventions. For this reason, micro-elimination as a 'bottom-up' approach may be a more feasible and efficient path to nationwide $\mathrm{HCV}$ elimination [3]. Various stakeholders involved in $\mathrm{HCV}$

(c) The Author(s). 2018 Open Access This article is distributed under the terms of the Creative Commons Attribution 4.0 International License (http://creativecommons.org/licenses/by/4.0/), which permits unrestricted use, distribution, and 
care have devoted their efforts to micro-elimination initiatives in the Netherlands, including: a) awareness campaigns directed at (ever) injection drug users and migrants but also health care workers; b) screening strategies in risk-groups to find undiagnosed persons with $\mathrm{HCV}$, as recommended by the national Health Council [4]; c) regional and nationwide retrieval projects of lost to follow-up previously diagnosed patients; d) HCV healthcare pathways in addiction clinics and primary care to promote and guide linkage to care; e) registry and close monitoring of $\mathrm{HCV}$ subpopulations (registry of $\mathrm{HIV} / \mathrm{HCV}$ coinfected managed by the Dutch HIV monitoring foundation and the hemophilia treatment center follows all $\mathrm{HCV}$ patients with hemophilia). However, the success of all (micro-) elimination efforts hinges on solid epidemiologic data on $\mathrm{HCV}$ prevalence and incidence in all $\mathrm{HCV}$ risk groups. Adequate registration and monitoring is an imperative element of $\mathrm{HCV}$ elimination and achieving this may be one of the most difficult obstacles to overcome in the elimination process.

This paper will describe (trends in) $\mathrm{HCV}$ epidemiology in the Netherlands, the micro-elimination progress in different $\mathrm{HCV}$ risk groups and also outline the strategies that have been employed by different stakeholders to improve uptake and retention in each step of the Dutch $\mathrm{HCV}$ healthcare cascade. Finally, we will elaborate on the Dutch progress towards nationwide $\mathrm{HCV}$ elimination and elucidate if the Netherlands may be among the first countries to achieve this final ambition in the near future.

\section{Hepatitis C prevalence and incidence in the Netherlands}

Although it is generally accepted that the Netherlands is a low prevalence region for $\mathrm{HCV}$, only few studies have ever been performed to ascertain its prevalence in the general population. Two cross-sectional serosurveys in 1996 and 2007 calculated a national prevalence of $0.1 \%$ and $0.3 \%$, respectively $[5,6]$. Of note, groups from $\mathrm{HCV}$ endemic regions were considered underrepresented in the '96 survey and therefore a higher proportion (70\%) of non-Dutch nationalities were included in the '07 survey. In 2012, Vriend et al. applied a different approach (i.e. the Workbook method) to estimate HCV prevalence in the Netherlands. The Workbook method incorporates lowest and highest available risk group based prevalence estimates which are subsequently multiplied by the different population sizes to generate an absolute number of $\mathrm{HCV}$ infected individuals per risk group. This study reported an estimated HCV seroprevalence of $0.22 \%$ which had been averaged from the lowest and highest total estimate of $0.07 \%$ and $0.37 \%$ respectively [7]. A recent update of this estimate, with more extensively defined prevalence estimates in different migrant populations, reported a $0.16 \% \mathrm{HCV}$ seroprevalence in the Netherlands in 2017, which is still very similar to the older estimates from ' 96 and ' 07 . This would correspond to 23,000 anti-HCV positive individuals in the Netherlands [8]. From a global perspective, it shows that the aforementioned HCV prevalence rate of $0.16 \%$ in the Netherlands is not only among the lowest in Western Europe but also one of the lowest worldwide [9-11]. Considering the HCV prevalence in distinct risk groups, the Dutch situation to some extent mimics the distribution in North America, Western Europe, and Australia, meaning that HCV infection is hyper endemic among people who (ever) inject(ed) drugs (PWID) (seroprevalence 39-74\%) [12-16]. However, ongoing viral transmission of hepatitis $C$ in the Dutch PWID group seems virtually non-existent: 44 cases of acute HCV were reported nationwide in 2016 of which $<5$ were associated with intravenous drug use [17]. This is in line with the very low level of injecting among current drug users (estimated to be less than 1000 drug injectors in the whole country, with high access to clean injecting equipment). Nevertheless, underreporting due to an asymptomatic disease course cannot be ruled out. The low HCV incidence in PWID can also in part be explained by the decline in injection drug use (IDU) after the problematic 1960-1970's as a consequence of overall diminished popularity but also due to the availability of physician-prescribed methadone treatment, needle exchange and other harm reduction programs $[18,19]$. In 2015 , the national number of recent injecting drug users was historically low $( \pm 500$ i.e. $6 \%$ of all opiate users in addiction care) [20]. In the Netherlands, the first generation migrants emerge quantitatively as the major contributor to the Dutch national HCV burden (41-70\%) [6-8]. However, the number of new infections due to immigration is not considered to have great impact on the total pool of chronically infected since the annual Dutch population growth as a cause of immigration is $<0.5 \%$ at the time of writing [21]. Also, the $\mathrm{HCV}$ prevalence in migrant populations in different nations has been described to be lower in comparison to the country of origin prevalence estimates [22]. The Netherlands, next to having a low prevalence, is also characterized by a low incidence of $\mathrm{HCV}$ infections that are mainly observed in the subgroup of HIV-infected persons (49 acute HCV infections in HIV-infected in 2016, i.e. 5.5/ 1000 person years, 95\% CI 4.1-7.2). It was recently reported that the Dutch incidence rate of acute $\mathrm{HCV}$ in this group has decreased considerably, which is illustrative of an effective "treatment as prevention" approach [23]. However, current re-infection rates in HIV-infected (34/1000 person years in 2016) are still high and predominantly related to the involvement of men who have sex with men (MSM) in high-risk sexual activities (including 'chemsex', i.e. sex under the influence of psychoactive drugs) [24]. 


\section{Hepatitis C treatment effectiveness in different subpopulations}

Various Dutch subpopulations with increased risk and/ or prevalence of $\mathrm{HCV}$ can be identified as possible target groups for micro-elimination: the 'low risk population', migrants from high endemic countries, PWID, individuals with HIV, prisoners, MSM, patients with hemophilia, hemodialysis patients and health care workers (Table 1). As mentioned previously, to determine the success of $\mathrm{HCV}$ therapy uptake in subpopulations or otherwise assess the $\mathrm{HCV}$ micro-elimination progress, adequate patient monitoring systems are essential. In the Netherlands, several risk groups are closely monitored and (detailed) information on HCV therapy uptake is available in subpopulations such as HCV/HIV coinfected and HCV patients with an inherited bleeding disorder [24, 25]. With regard to the Dutch HIV population, annual screening for $\mathrm{HCV}$ infection is performed in those HIV positives in treatment with ongoing risk factors / behavior, irrespective of the presence of symptoms. Data from the Dutch HIV monitoring foundation (SHM), that includes $98 \%$ of all HIV-infected individuals who are retained in care, indicated that virtually all patients $(n=1439 ; 96.6 \%)$ had been screened at least once for HCV infection in 2017 [24]. Of note, the number of undiagnosed $\mathrm{HIV} / \mathrm{HCV}$ coinfections is believed to be low (6\% of the estimated 1750 undiagnosed Dutch HIV-infections) [24, 26]. Of those monitored HCV/HIV coinfected patients, $76 \%$ had been cured by February 2017 and from another 6\% DAA therapy results were pending, totaling more than $80 \%$ clearance rate for this population [27]. Secondly, the van Creveldkliniek hemophilia treatment center (University Medical Center

Table 1 Hepatitis C micro-elimination progress in target populations in the Netherlands in 2017

\begin{tabular}{|c|c|c|c|c|c|c|}
\hline & $\begin{array}{l}\text { Population } \\
\text { size }(\mathrm{N})\end{array}$ & $\begin{array}{l}\mathrm{HCV} \\
\text { seroprevalence } \\
(\%)\end{array}$ & $\begin{array}{l}\text { Total chronic } \\
\text { HCV infections } \\
(H C V \text { RNA }(+))(N)\end{array}$ & $\begin{array}{l}\text { HCV infections } \\
\text { cured }(N) /(\%)\end{array}$ & Source/Comments & $\begin{array}{l}\text { Main actions/interventions to } \\
\text { facilitate HCV elimination }\end{array}$ \\
\hline HIV-infected & 22,900 & $12 \%$ & $1471(R)$ & $1124 / 76 \%$ & {$[24,27]$} & $\begin{array}{l}\text { - Behavioral counseling. } \\
\text { - Once in a lifetime or frequent }{ }^{c} \\
\text { screening (depending on } \\
\text { risk behavior). }\end{array}$ \\
\hline $\begin{array}{l}\text { Hemophilia patients } \\
\text { (born < 1992) }\end{array}$ & NA & NA & $700(R)$ & $190 / 27.1 \%$ & $\begin{array}{l}\text { [25] (Combined } \\
\text { Dutch \& UK cohort) }\end{array}$ & $\begin{array}{l}\text { - Once in a lifetime screening. } \\
\text { - Treatment scale-up. }\end{array}$ \\
\hline $\begin{array}{l}\text { High-risk MSM } \\
\text { (HIV-negative) }^{b}\end{array}$ & NA & $4,8 \%$ & NA & NA/NA & {$[57]$} & $\begin{array}{l}\text { - Behavioral counseling. } \\
\text { - Frequent }{ }^{c} \text { screening } \\
\text { - Early treatment in case of (re) infection. }\end{array}$ \\
\hline $\begin{array}{l}\text { Migrants from high } \\
\text { endemic countries }\end{array}$ & $1,527,032$ & NA & $13,819(E)$ & NA/NA & {$[58]$} & $\begin{array}{l}\text { - Raise awareness of HCV through local/ } \\
\text { multimedia information campaigns. } \\
\text { - Once in a lifetime screening for } \\
\text { first-generation migrants with HCV } \\
\text { prevalence } \geq 2 \% \text { in country of origin. }\end{array}$ \\
\hline PWID & 14,000 & $39-74 \%$ & $4040-7666(C)$ & NA/NA & {$[7,12-16,59]$} & $\begin{array}{l}\text { - Once in a lifetime or frequent }{ }^{c} \\
\text { screening (depending on risk behavior). } \\
\text { - Treatment scale up. }\end{array}$ \\
\hline Prisoners & 10,194/each day & $7.4-13.9 \%$ & $558-1049(C)$ & NA/NA & {$[60-62]$} & $\begin{array}{l}\text { - Educate prison doctors on HCV. } \\
\text { - Once in a lifetime or frequent }{ }^{c} \\
\text { screening (depending on risk behavior). } \\
\text { - Include detainees in regular health } \\
\text { insurance. }\end{array}$ \\
\hline $\begin{array}{l}\text { Hemodialysis } \\
\text { patients }\end{array}$ & 17,132 & NA & NA & NA/NA & {$[63]$} & - Once in a lifetime screening. \\
\hline $\begin{array}{l}\text { Health care } \\
\text { workers }^{d}\end{array}$ & NA & NA & NA & NA/NA & - & - Once in a lifetime screening by employer. \\
\hline $\begin{array}{l}\text { General Dutch } \\
\text { population }\end{array}$ & $17,081,507^{\mathrm{a}}$ & $0.1-0.4 \%$ & $12,640-50,561(C)$ & $4427 / 8-35 \%$ & {$[7,29]$} & $\begin{array}{l}\text { - Raise awareness of HCV through } \\
\text { multimedia information campaigns. } \\
\text { - Educate general practitioners on HCV } \\
\text { to increase compliance with viral hepatitis } \\
\text { screening and referral guidelines. } \\
\text { - Trace and treat HCV infected lost } \\
\text { to follow-up. }\end{array}$ \\
\hline
\end{tabular}

PWID people who (have ever) inject(ed) drugs, MSM men who have sex with men, NA not available. (R) = reported numbers from publications of registries; $(E)$ = estimated numbers reported in studies; $(C)=$ calculated from seroprevalence estimates multiplied by .74 (assumed spontaneous clearance rate of $26 \%$ )

a https://opendata.cbs.nl/statline/\#/CBS/nl, Dutch population numbers in 2017

${ }^{b}$ MSM with high-risk sexual activities

c One to four times per year

${ }^{d}$ Health care workers who perform hazardous tasks, putting them at risk for acquiring of transferring a hepatitis $\mathrm{C}$ infection (definition from the National Health Council) [4] 
Utrecht, The Netherlands) reported that $27 \%$ of all 700 chronic HCV patients with an inherited bleeding disorder from a combined Dutch and UK cohort had been cured in April 2012 [25]. This proportion of cured patients, like in the $\mathrm{HCV} / \mathrm{HIV}$ co-infected population, is expected to have increased dramatically since DAA-therapy became available.

Also, the transmission of $\mathrm{HCV}$ to hemophilia patients due contaminated blood products has been halted with the introduction of anti-HCV testing in blood donors and of recombinant clotting factors [28]. Finally, data obtained from the Drug Information System of the National Health Care Institute (GIP) illustrate that between the years 2009 until the availability of DAAs in 2015 an estimated 4427 persons with HCV have been cured in the Netherlands (i.e. $19 \%$ of the $\pm 23,000$ estimated HCV antibody positive individuals) [29]. With regard to the remaining $\mathrm{HCV}$ risk groups, exact data is lacking and no reliable estimate of DAA therapy uptake in these subpopulations could be made. A HCV prevalence estimate was available in a number of groups (Table 1).

\section{Dutch hepatitis C healthcare cascade: Strategies towards micro-elimination}

\section{Awareness and prevention}

A summary of the main Dutch strategies towards HCV elimination is depicted in Fig. 1. In the Netherlands, several institutions involved in public healthcare are dedicated to increasing awareness and knowledge of HCV in risk groups and as well as in the general population. To this end, a large nation-wide multimedia HCV awareness campaign was implemented in 2009/2010, targeting individuals attending methadone clinics and also risk groups in the general population. In participating methadone clinics $\mathrm{HCV}$ test uptake was $62 \%$ during the campaign. At the end of the project, 257 additional $\mathrm{HCV}$-carriers had been identified in methadone clinic attendees and the intervention was judged to be cost-effective in this group. In contrast, the intervention was not cost-effective in the general population although the number of anti-HCV tests in 25 laboratories had increased by $12.9 \%$ in comparison with previous years [30]. At the annual Dutch National Hepatitis Day in November 2017, another compendious media campaign with both radio and television broadcasts was launched by the Dutch Liver Patient Association (NLV) to raise awareness among patients, physicians but also health policymakers for the increasing Dutch mortality rates as a cause of viral hepatitis [31]. This campaign has reached over ten million persons in the Netherlands (personal communication José Willemse, Executive director NLV).

\section{Testing and diagnosis: Screening and retrieval projects}

A key factor in achieving HCV elimination lies in augmenting the case finding rate. Case finding can be further classified as: i) the identification of undiagnosed $\mathrm{HCV}$ patients (i.e. screening) and ii) tracing of previously diagnosed patients who are no longer in clinical care (i.e. retrieval). Since migrants have been shown to account for the majority of HCV infections in the Netherlands, several large screening projects in migrant groups from high endemic countries (a.o. Afghanistan, China, Egypt, Iraq, Turkey, Poland) have been performed. The yield of these projects however was low, despite the use of peers in some projects, and only a handful of viremic $\mathrm{HCV}$ (1-10 persons per project, i.e. $0.1-4.8 \%)$ were identified of which also a small number was already aware of their disease [32-38]. These low results could be explained by a 'healthy volunteer' effect which indicates that the participants of screening projects are in fact healthier than the index population [39]. Further initiatives are therefore still needed to encourage more individuals with a migration background to get tested for HCV. This is also supported by the Dutch National Health Council (HC) who as of November 2016 recommends HCV screening in all first generation migrant populations with

\begin{tabular}{|c|c|c|c|c|}
\hline $\begin{array}{l}\text { Awareness and } \\
\text { prevention (1) }\end{array}$ & $\begin{array}{l}\text { Testing and } \\
\text { diagnosis (2) }\end{array}$ & $\begin{array}{l}\text { Linkage to } \\
\text { care (3) }\end{array}$ & $\begin{array}{c}\text { Access to medication } \\
\text { and qualified health } \\
\text { services (4) }\end{array}$ & $\begin{array}{l}\text { Monotoring and } \\
\text { evaluation (5) }\end{array}$ \\
\hline $\begin{array}{l}\text { Information } \\
\text { campaigns (PCP, } \\
\text { risk groups) }\end{array}$ & $\begin{array}{l}\text { Screening } \\
\text { projects }\end{array}$ & $\begin{array}{l}\text { HCV healthcare } \\
\text { pathways in } \\
\text { addiction care }\end{array}$ & $\begin{array}{l}\text { Full coverage DAA } \\
\text { therapy by health } \\
\text { insurance }\end{array}$ & $\begin{array}{l}\text { Pilot national HCV } \\
\text { registry }\end{array}$ \\
\hline $\begin{array}{l}\text { Burden of disease } \\
\text { estimates }\end{array}$ & $\begin{array}{c:c}\text { Retrieval of LFU } & \\
\text { diagnosed } & \\
\text { patients } & \end{array}$ & $\begin{array}{l}\text { PCP screening } \\
\text { and referral } \\
\text { guidelines }\end{array}$ & $\begin{array}{l}\text { Designated hepatitis } \\
\text { treatment centers }\end{array}$ & $\begin{array}{l}\text { Mandatory report of } \\
\text { acute and chronic* } \\
\text { HCV }\end{array}$ \\
\hline \multicolumn{5}{|c|}{$\begin{array}{l}\text { LFU, lost to follow-up; PCP, primary care physician. * implementation of mandatory report of chronic HCV is } \\
\text { advised } \\
\text { Fig. } 1 \text { Dutch HCV care cascade }\end{array}$} \\
\hline
\end{tabular}


a known $\mathrm{HCV}$ prevalence in the country of origin of $\geq 2 \%$. At the moment however, screening projects targeting migrant populations at locations other than primary care practices, require approval from the Ministry of Health, Welfare and Sport (VWS) [4]. This prerequisite poses a barrier for renewed screening efforts in migrant subgroups (last project dates from 2013) in the present DAA-era in which therapeutic options have improved immensely. Consequently, HCV screening in first generation migrants currently falls under the responsibility of Primary Care Physicians (PCPs) in the Netherlands who are guided by their evidence-based professional 'guideline on viral hepatitis' from the Dutch College of General Practitioners (NHG) [40]. The NHG guideline in addition promotes screening in individuals with an increased ALT ( $\geq 1.5$ times the upper limit of normal) in the general population who may have been at risk for $\mathrm{HCV}$ infection. However, due to the small number of hepatitis patients in each PCP practice and the limited knowledge on hepatitis, screening of hepatitis in PCP practices is suboptimal. Another subgroup with high HCV prevalence (Table 1) deserving enhanced screening efforts is the detention population. Although the Dutch Custodial Institution Agency introduced updated guidelines on HCV screening in 2016, promoting HCV screening upon confinement for those who have been at risk, non-compliance with those guidelines occurs regularly and the frequent relocation of detainees further complicates treatment initiation and adherence. In addition, the Ministry of Justice finances the Dutch prison healthcare system and reimbursing DAA-therapy poses a heavy burden on its total health care budget. This constitutes another barrier for testing and treating $\mathrm{HCV}$-infected detainees.

Next to screenings projects, several retrieval projects of diagnosed patients who have been lost to follow-up have been executed in various regions in the Netherlands. Projects were initiated by different physicians involved in care for hepatitis patients: hospital based specialists (Gastroenterology, Infectious Diseases and Microbiology), PCPs, but also Public Health physicians. The most commonly applied method in those retrieval projects was the reevaluation of positive $\mathrm{HCV}$ diagnostics from the past 10-15 years from microbiological laboratories in order to identify untreated patients. Patients with presumed persistent $\mathrm{HCV}$ would then be reevaluated by their PCP and, if appropriate, invited back into clinical care. The proportion of chronic $\mathrm{HCV}$ patients who were lost to follow-up was reported to be as high as 38\% [41-43]. Results of the main (published) Dutch retrieval projects are summarized in Fig. 3. The largest retrieval effort in the center of the Netherlands (REACH-project) has been the most successful thus far with $28.3 \%$ of all lost to follow-up patients traced [44]. One of the success factors may be that, in contrast to other endeavors, in the REACH-project patients were invited directly at the outpatient clinic without interference of the general practitioner. The REACH-project served as a pilot and subsequent nationwide roll-out of $\mathrm{HCV}$ retrieval is scheduled to start in 2018 (CELINE). The CELINE initiative constitutes a collaboration between hepatologists and Infectious diseases physicians of all eight Dutch Academic Medical Centers (HepNED) and aims to realize case ascertainment in $>50 \%$ those who previously tested positive for $\mathrm{HCV}$ in the next 3 years and also to include 95\% of retrieved patients in a national registry [45].

\section{Linkage to care}

The Dutch national plan on viral hepatitis underlined the importance of regional, multi-stakeholder, healthcare networks (i.e. hepatitis teams) in order to monitor and safeguard the local identification and linkage to care of $\mathrm{HCV}$ patients from all different risk group [2]. Such hepatitis teams have been installed successfully in various regions (Arnhem, Utrecht) and may serve as an example for other districts [32]. The "Breakthrough Project", initiated by the Netherlands Institute of Mental Health and Addiction (Trimbos Institute) is another example of a collaborative between various stakeholders. The Trimbos Institute aspired to structurally improve the detection and linkage to care of $\mathrm{HCV}$ in Dutch addiction care clinics and to develop sustainable HCV referral cascades. To this end, two implementation projects based on the Breakthrough methodology (Breakthrough Project) were initiated between 2013 and 2016. Multiple multidisciplinary teams, including Gastroenterology specialists from a (nearby) hepatitis treatment center and nurses, medical doctors and managers from the local addiction care center, created a local and sustainable HCV referral pathway to secure linkage to care. Final results of the project are pending.

\section{Access to medication and qualified health services}

In the Netherlands, virtually all patients have good access to healthcare and also, once diagnosed with $\mathrm{HCV}$, to DAA therapy. As of November 2015, all available DAAs are reimbursed by basic health care insurance (which is obligatory in the Netherlands) irrespective of fibrosis stage, alcohol or drug use status. Basic healthcare insurance in the Netherlands however includes obligatory deductible excess, which added up to 385 euro per year in 2017 and 2018. This amount has to be paid by the policy holder before an insurance providers covers any expenses and may negatively affect one's willingness to get tested for $\mathrm{HCV}$, especially in individuals with lower socio-economic status. On average, the obligatory deductible excess is fully spend by $50 \%$ of all insured individuals annually [46]. As described previously, the Ministry of Justice pays DAA therapy costs for individuals in detention. Asylum seekers can be considered 
for HCV treatment, but only when a residence permit is granted.

Although a wide variety of stakeholders is involved in the detection of and care for patients with a chronic $\mathrm{HCV}$ infection in the Netherlands (Fig. 2), until now treatment of $\mathrm{HCV}$ remains under the responsibility of hospital-based-physicians (specialists in hepatology or infectious diseases physicians working in designated hepatitis centers). There are 45 designated hepatitis centers in the Netherlands (Fig. 3) which can all be attended to on referral by the PCP. Physicians in all hepatitis treatment centers can consult the Dutch national "guidebook" on HCV treatment (www.HCVrichtsnoer.nl) that summarizes the recommendations of the main international guidelines on HCV treatment. The 'HCV richtsnoer' provides guidance for the appropriate DAA regimen selection with an update being published after each major international guideline revision [47].

\section{Monitoring and evaluation}

Adequate monitoring and registration of all patients in each step of the HCV healthcare cascade is essential to achieve HCV elimination. When drop out at any of the stages of the HCV healthcare cascade has been reduced to zero, elimination will have been achieved. By the Dutch public health act, in 1999 it became mandatory to report acute $\mathrm{HCV}$ infections to the local Public Health Services and hence incident infections are recorded since then. Until now, chronic HCV infections do not require notification but this is about to change in 2018. In addition, a pilot project was initiated in 2017 by the Dutch Association of Internal Medicine (NIV) and Gastroenterology and Hepatology (NVMDL) specialists with 8 participating hospitals aiming to create a registry for treatment uptake and outcome of all viral hepatitis $B$ \& $C$ mono-infections. This project was able to benefit from the existing registration system of the HIV Monitoring Foundation (SHM) that has already been used to monitor both HIV-mono and HIV/hepatitis B or C co-infected patients for decades [48]. The previously mentioned national retrieval project CELINE aspires to further, both retrospectively and prospectively, complete this registry in the upcoming years.

The Dutch Central Bureau of Statistics (CBS) collects data on the primary cause of death in the general population and based on this information, the annual viral hepatitis C and B related mortality was estimated at $+/-$

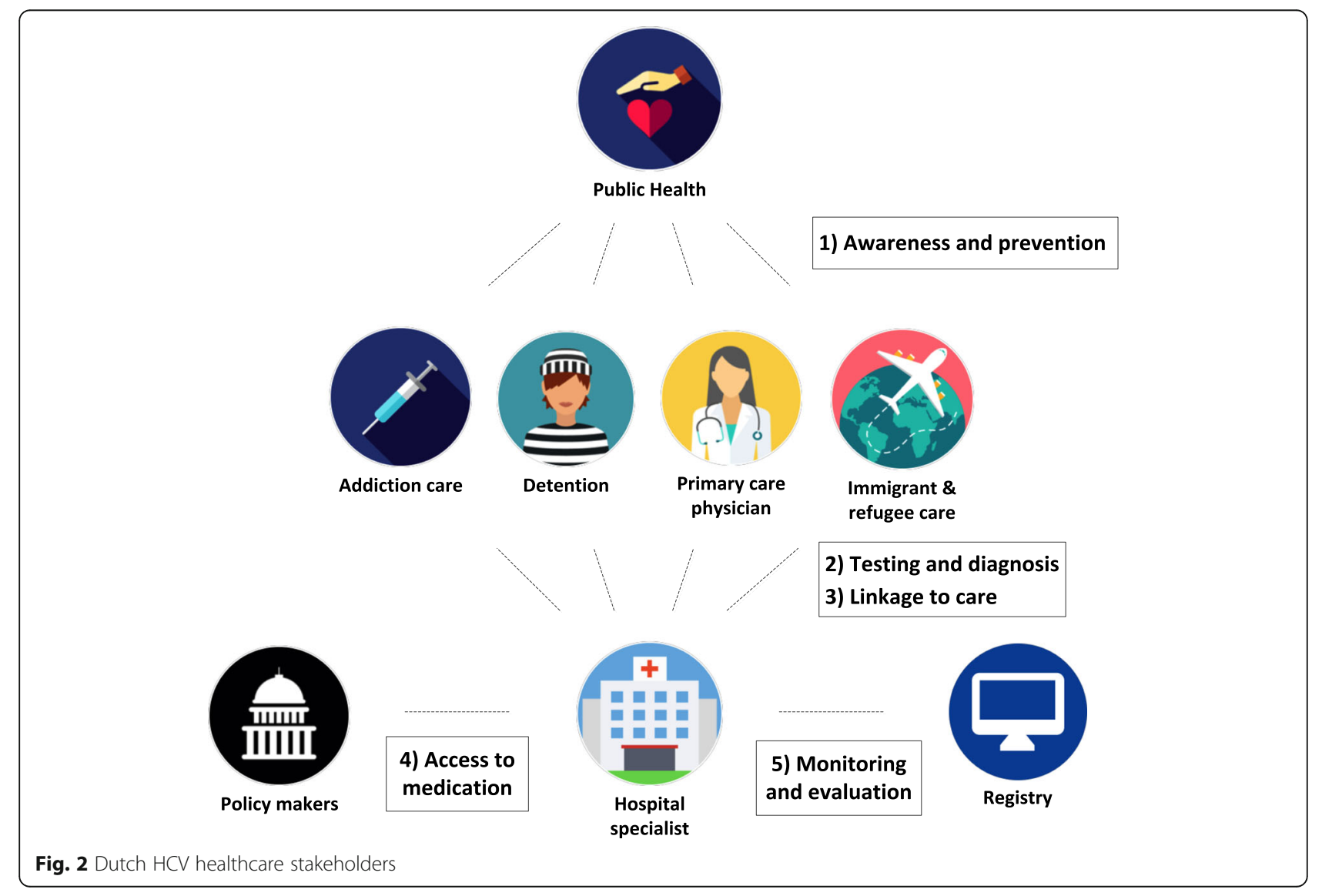




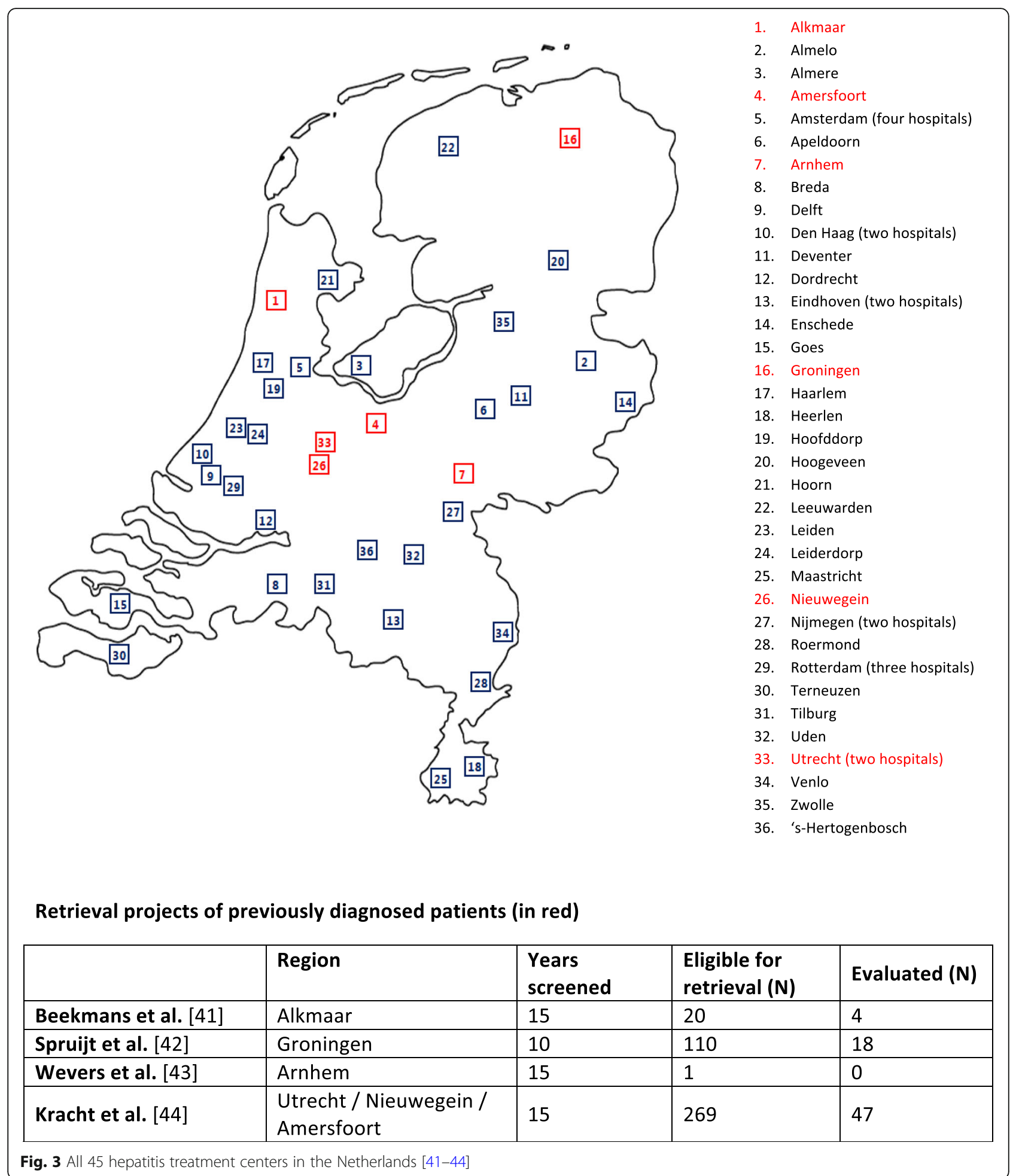

500 deaths per year between 2002 and 2015 [31]. The viral hepatitis related mortality has not yet decreased as a consequence of the introduction of DAA-therapy. The van Creveldkliniek hemophilia treatment center reported a mortality rate of $28 \%$ in patients with hemophilia and chronic HCV of which $28 \%$ was liver-related (median follow-up of 31 years since HCV infection) [25]. These numbers however date from the pre-DAA era. The SHM registers the cause of death in HIV mono- and $\mathrm{HIV} / \mathrm{HCV}$ coinfected however viral hepatitis related mortality in $\mathrm{HIV} / \mathrm{HCV}$ coinfected individuals has not been explicitly described [24]. 


\section{Future direction for hepatitis C (micro-) elimination in the Netherlands}

The present Dutch situation with low HCV seroprevalence $(0.1-0.4 \%)[7,11]$ and a limited number of new infections $[17,23]$ is an excellent starting point for final $\mathrm{HCV}$ elimination. Some experts argue that the proportion of undiagnosed or 'hidden' HCV patients may actually be smaller than previously estimated as exemplified by a large high prevalence birth cohort screening project in the South of the Netherlands ( $n=3434$ patients) that did not identify any active HCV infections [49]. A study modelling the future $\mathrm{HCV}$ burden of disease in the Netherlands estimated an $85 \%$ reduction in chronic HCV infections by the year 2030, if treatment rate can be scaled up adequately [50]. In the past years, numerous Dutch micro-elimination projects have consequently put their efforts into enhancing the screening, linkage to care and finally the $\mathrm{HCV}$ treatment uptake in various risk group populations [27, 30, 32-35, 37, 38, 41-43]. Taking all endeavors into account, a drastic future reduction in the Dutch pool of chronic $\mathrm{HCV}$-infected can be envisioned.

Important caveats however do remain in various stages of the Dutch HCV continuum of care which will have to be addressed before HCV micro-elimination can be achieved. First of all, the proportion of chronic HCV patients who has been lost to follow-up is substantial [41-43]. The nationwide roll out of the pilot project for retrieval but also registration of viral hepatitis $C$ mono-infections (CELINE) therefore constitutes an important challenge to complete in the near future [45]. Secondly, as can be observed in the micro-elimination table, data on exact prevalence and therapy uptake is still unknown for many target groups (Table 1). The progress against $\mathrm{HCV}$ can thus not be tracked appropriately. When successfully executed, CELINE will substantially contribute to overcoming this issue by entering the data of $>95 \%$ of previously diagnosed $\mathrm{HCV}$ patients who have been retrieved in a central registry. Thirdly, despite the existence of various professional $\mathrm{HCV}$ screening guidelines, current screening strategies do not adequately target several high prevalence risk groups and a considerable group might still be unware of their disease. Specific improvements have to be made in the identification and linkage to care of $\mathrm{HCV}$ patients in addiction care centers, those originating from high endemic $\mathrm{HCV}$ countries immigrating to the Netherlands and also the general population as they constitute the major contributors to the Dutch HCV burden of disease (although overestimation of the $\mathrm{HCV}$ prevalence cannot be ruled out) [7]. Also, HIV-negative MSM who engage in high-risk sexual behavior (e.g. those receiving HIV Pre-Exposure Prophylaxis or PrEP) recently emerged as another subgroup with a relatively high $\mathrm{HCV}$ incidence $(0.7-1.3$ per 100 person-years) [51-53]. In the SHM HIV/HCV coinfected cohort, high DAA-therapy uptake of $76 \%$ has led to a decrease in HCV incident infections by half (from 11.2 to 5.5 per 1000 person-years) but a substantial (re-) infection rate remains [23]. Modeling studies describe that behavioral counseling in addition to treatment scale-up may be effective in further reducing the long-term $\mathrm{HCV}$ prevalence $[54,55]$.

With the current diminishing prevalence, the upcoming challenge will be to improve case finding strategies in order to accomplish higher treatment rates and to avoid a 'diagnostic burn-out' (i.e. the amount of treatments is reduced to zero because patients remain unware of their disease and therefore will not receive therapy) [56]. This diagnostic endeavor is preferably taken on by the PCPs as they encounter the majority of the Dutch population at risk for $\mathrm{HCV}$ in their practices. Since knowledge of HCV in Dutch PCPs is deemed insufficient, focus should shift towards educating PCPs about viral hepatitis $\mathrm{C}$. With the current simplified DAA therapy regimens, treatment of patients with none to mild fibrosis may even be transferred to the PCPs in the future.

\section{Conclusion}

The current Dutch HCV epidemiology with both low prevalence and incidence in combination with universal access to DAA therapy, favors a future $\mathrm{HCV}$ elimination scenario. The micro-elimination method, that delivers targeted interventions at pre-defined HCV risk groups, is frequently applied to improve the Dutch HCV healthcare cascade and constitutes a pragmatic and efficient approach. To avoid an eventual diagnostic burn-out, efforts towards case-finding should be intensified. Although challenges remain, the Netherlands continues to be one of the global frontrunners in its efforts to national viral hepatitis $\mathrm{C}$ elimination. Whether this goal may actually be achieved by the year 2030, remains to be elucidated in the next couple of years.

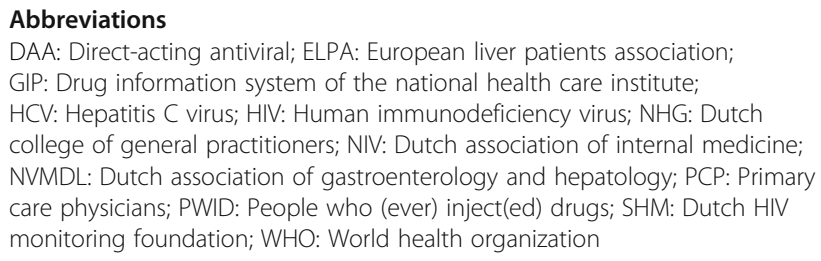

Availability of data and materials

Data sharing is not applicable to this article as no datasets were generated or analysed during the current study.

Declarations

Publication charges for this article have been funded by MSD. 


\section{Authors' contributions}

PK, JA and EC contributed to drafting the manuscript; KE, AU, JW and $\mathrm{AH}$ critically revised the manuscript for intellectual content. All authors read and approved the final to be submitted manuscript.

\section{Ethics approval and consent to participate}

Not applicable.

\section{Consent for publication}

Not applicable.

\section{Competing interests}

AH: advisory boards: Abbvie, BMS, Gilead, Janssen, MSD; consultancy: AbbVie; financial support for HCV retrieval project from Abbvie, BMS, Gilead and MSD; JA: advisory boards: Abbvie, BMS, Gilead, Janssen, MSD and ViiV; research grants: AbbVie, BMS; KvE: advisory boards: Abbvie, BMS, Gilead, Janssen-Cilag; Support for HCV patient care path from Abbvie, Gilead, Janssen-Cilag. The other authors declare that they have no competing interest.

\section{Publisher's Note}

Springer Nature remains neutral with regard to jurisdictional claims in published maps and institutional affiliations.

\section{Author details}

'Department of Internal medicine and Infectious disease, Utrecht University, University Medical Center Utrecht, Utrecht, the Netherlands. ${ }^{2}$ Department of Gastroenterology and Hepatology, Utrecht University, University Medical Center Utrecht, Utrecht, the Netherlands. ${ }^{3}$ Centre for Infectious Disease Control, National Institute for Public Health and the Environment, Bilthoven, The Netherlands. ${ }^{4}$ Dutch Liver Patient Association (NLV), Hoogland, the Netherlands. ${ }^{5}$ Netherlands Institute of Mental Health and Addiction (Trimbos Institute), Utrecht, the Netherlands.

Received: 23 April 2018 Accepted: 20 September 2018

Published online: 29 September 2018

\section{References}

1. World Health Organization. Global health sector strategy on viral hepatitis 2016-2021. 2016. http://apps.who.int/iris/bitstream/handle/10665/246177/ WHO-HIV-2016.06-eng.pdf; jsessionid=

C9A6E8F12C8AFB281EAEDC0C2ABA6EE9? sequence=1. Accessed 2 Apr 2018.

2. Hogenbirk R, David S, van Steenbergen J, Urbanus A. Meer dan opsporen Nationaal hepatitisplan: een strategie voor actie. 2016. http://www.rivm.nl/ dsresource?objectid=119820d5-d1fe-440f-83cf-ffb7478f0282\&type $=$ pdf\&disposition=inline. Accessed 2 Apr 2018

3. Lazarus JV, Wiktor S, Colombo M, Thursz M. EASL international Liver Foundation. Micro-elimination - a path to global elimination of hepatitis C. J Hepatol. 2017;67(4):665-6.

4. Health Council of the Netherlands. Screening risk groups for hepatitis B and C. The Haque: Health Council of the Netherlands; 2016. https://www. gezondheidsraad.nl/documenten/adviezen/2016/11/01/screening-vanrisicogroepen-op-hepatitis-b-en-c. Accessed 2 Apr 2018

5. Veldhuijzen IK, Conyn-van Spaendonck MAE, Dorigo-Zetsma JW Seroprevalence of hepatitis B and C in the Dutch population. Infect Bull. 1999;10:182-4

6. Vriend HJ, Op de Coul ELM, van de Laar TJW, Urbanus AT, van der Klis FRM, Boot HJ. Hepatitis C virus seroprevalence in the Netherlands. Eur J Pub Health. 2012;22(6):819-21.

7. Vriend HJ, Van Veen MG, Prins M, Urbanus AT, Boot HJ, Op De Coul ELM Hepatitis $C$ virus prevalence in the Netherlands: migrants account for most infections. Epidemiol Infect. 2013;141(6):1310-7.

8. Koopsen J, van Steenbergen J, Richardus JH, Prins M, Op De Coul ELM, Croes EA, et al. Chronic hepatitis B and C infections in the Netherlands: estimated prevalence in risk groups and the general population. J Hepatol. 2018:68:5156-7.

9. Blach S, Zeuzem S, Manns M, Altraif I, Duberg A-S, Muljono DH, et al. Global prevalence and genotype distribution of hepatitis $C$ virus infection in 2015: a modelling study. Lancet Gastroenterol Hepatol. 2017;2(3):161-76.
10. Petruzziello A, Marigliano S, Loquercio G, Cacciapuoti C. Hepatitis C virus ( $\mathrm{HCV}$ ) genotypes distribution: an epidemiological up-date in Europe. Infect Agent Cancer. 2016;11(1):53.

11. European Union HCV Collaborators H, Robbins S, Zeuzem S, Negro F, Buti M, Duberg A-S, et al. Hepatitis C virus prevalence and level of intervention required to achieve the WHO targets for elimination in the European Union by 2030: a modelling study. Lancet Gastroenterol Hepatol. 2017;2(5):325-36.

12. Lindenburg CEA, Lambers FAE, Urbanus AT, Schinkel J, Jansen PLM, Krol A, et al. Hepatitis $C$ testing and treatment among active drug users in Amsterdam: results from the DUTCH-C project. Eur J Gastroenterol Hepatol. 2011;23(1):23-31.

13. van den Hoek JA, van Haastrecht HJ, Goudsmit J, de Wolf F, Coutinho RA Prevalence, incidence, and risk factors of hepatitis $C$ virus infection among drug users in Amsterdam. J Infect Dis. 1990;162(4):823-6.

14. Rondy M, Wiessing L, Hutchinson SJ, Matheï C, Mathis F, Mravcik V, et al. Hepatitis C prevalence in injecting drug users in Europe, 1990-2007: impact of study recruitment setting. Epidemiol Infect. 2013;141(03):563-72.

15. van Santen DK, van der Helm JJ, Lindenburg K, van der Schim Loeff M, Prins M. HIV and hepatitis C treatment uptake among people who use drugs participating in the Amsterdam cohort studies, 1985-2015. Int J Drug Policy. 2017:47:95-101.

16. Schreuder I, van der Sande MA, de Wit M, Bongaerts M, Boucher CA, Croes EA, et al. Seroprevalence of HIV, hepatitis $b$, and hepatitis $c$ among opioid drug users on methadone treatment in the Netherlands. Harm Reduct J. 2010;7(1):25

17. Visser M, van Aar F, van Oeffelen A, van den Broek I, Op De Coul E, Hofstraat $\mathrm{S}$, et al. Sexually transmitted infections including HIV, in the Netherlands in 2016. RIVM Rep 2017-0003. 2017. https://www.rivm.nl/ dsresource?objectid=7b76e243-ca01-40d2-b50d-af67c2a0b83f\&type $=$ pdf\&disposition=inline. Accessed 2 Apr 2018.

18. van de Laar TJW, Langendam MW, Bruisten SM, Welp EAE, Verhaest I, van Ameijden EJC, et al. Changes in risk behavior and dynamics of hepatitis $C$ virus infections among young drug users in Amsterdam, the Netherlands. J Med Virol. 2005;77(4):509-18.

19. Van Den Berg C, Smit C, Van Brussel G, Coutinho R, Prins M, Amsterdam Cohort. Full participation in harm reduction programmes is associated with decreased risk for human immunodeficiency virus and hepatitis $C$ virus: evidence from the Amsterdam cohort studies among drug users. Addiction. 2007;102(9):1454-62

20. Wisselink DJ, Kuijpers WGT, Mol A. Kerncijfers Verslavingszorg 2015. Landelijk Alcohol en Drugs Informatie Systeem (LADIS). 2015. http://www. ggznederland.nl/uploads/assets/Werkdocument\%20KC\%202015\%20.pdf KC 2015.pdf. Accessed 2018 Apr 2

21. Central Bureau of Statistics Open data StatLine. Dutch population numbers in 2017. https://opendata.cbs.nl/statline/\#/CBS/nl/dataset/37556/table?ts= 1537815690008. Accessed 2 Apr 2018.

22. European Centre for Disease Prevention and Control. Epidemiological assessment of hepatitis B and C among migrants in the EU / EEA. 2016. https://ecdc.europa.eu/sites/portal/files/media/en/publications/Publications/ epidemiological-assessment-hepatitis-B-and-C-among-migrants-EU-EEA.pdf. Accessed 2 Apr 2018.

23. Boerekamps A, Van den Berk GE, Fanny LN, Leyten EM, Van Kasteren ME, van Eeden A, et al. Declining HCV incidence in Dutch HIV positive men who have sex with men after unrestricted access to HCV therapy. Clin Infect Dis. 2018:66(9):1360-5.

24. van Sighem A, Boender S, Wit F, Smit C, Matser A, Reiss P. Monitoring report 2017. Human immunodeficiency virus (HIV) infection in the Netherlands. Stichting HIV Monitoring. 2017. https://www.hiv-monitoring.nl/files/1115/ 1117/7706/HIV_Monitoring_Report_2017.pdf. Accessed 2 Apr 2018.

25. van de Fransen Putte DE, Makris M, Fischer K, Yee TT, Kirk L, van Erpecum $\mathrm{KJ}$, et al. Long-term follow-up of hepatitis $\mathrm{C}$ infection in a large cohort of patients with inherited bleeding disorders. J Hepatol. 2014;60(1):39-45.

26. van Sighem A, Nakagawa F, De Angelis D, Quinten C, Bezemer D, de Coul EO, et al. Estimating HIV incidence, time to diagnosis, and the undiagnosed HIV epidemic using routine surveillance data. Epidemiology. 2015;26(5):653-60.

27. Boerekamps A, Newsum AM, Smit C, Arends JE, Richter C, Reiss P, et al. High treatment uptake in HIV/HCV-coinfected patients after unrestricted access to direct-acting antivirals in the Netherlands. Clin Infect Dis. 2018;66(9): 1352-9. 
28. Mauser-Bunschoten EP, Bresters D, van Drimmelen AA, Roosendaal G, Cuypers HT, Reesink HW, et al. Hepatitis C infection and viremia in Dutch hemophilia patients. J Med Virol. 1995;45(3):241-6.

29. Hofman R, Schalm SW, Richardus J. How many hepatitis B and C patients have been treated in the Netherlands? [article in Dutch]. LEVER. 2017;2:11-2.

30. Helsper CW, Janssen MP, van Essen GA, Croes EA, van der Veen C, de Wit $A G$, et al. Effectiveness and cost-effectiveness of nationwide campaigns for awareness and case finding of hepatitis $C$ targeted at people who inject drugs and the general population in the Netherlands. Int J Drug Policy. 2017:47:117-25.

31. Hofman R, Nusselder WJ, Veldhuijzen IK, Richardus JH. Mortality due to chronic viral hepatitis B and C infections in the Netherlands. Ned Tijdschr Geneeskd. 2016;160(0):D511.

32. Richter C, Ter Beest G, Gisolf EH, Van Bentum P, Waegemaekers C, Swanink $C$, et al. Screening for chronic hepatitis $B$ and $C$ in migrants from Afghanistan, Iran, Iraq, the former soviet republics, and Vietnam in the Arnhem region, the Netherlands. Epidemiol Infect. 2014;142(10):2140-6.

33. Van Diemen AJ, Van Heerwaarden A, Schout C, Medisch U, Utrecht C. Onderzoek in het kort China onder de Dom Hepatitis B- en C-screening bij Chinese migranten in Utrecht. Infect Bull. 2011;1:19-21.

34. Grintjes K, MANP ASM, Dofferhoff F, Stelma RPM, Koene R, van Crevel M Van den Muijsenbergh PPK. Hepatitis C-opsporing onder migranten in Nijmegen (HECOM). 2014;9(5):126-33.

35. Zuure FR, Bouman J, Martens M, Vanhommerig JW, Urbanus AT, Davidovich $U$, et al. Screening for hepatitis B and C in first-generation Egyptian migrants living in the Netherlands. Liver Int. 2013;33(5):727-38.

36. Urbanus AT, Steenbergen van JE. Hepatitis B-virus en hepatitis C-virus screeningsprojecten voor migranten in Nederland : stand van zaken 2014. Tijdschr voor Infect. 2015;10(2):31-6.

37. Hepatitis Info. http://www.hepatitisinfo.nl/projecten/screening/DU2558 Screening-en-bewustzijnsbevordering-hepatitis-B-en-hepatitis-C-bijChinezen-in-Nederland-2009-2013.aspx. Accessed 2 Apr 2018

38. Richter C, Ter BG, Sancak I, Aydinly R, Bulbul K, Laetemia-Tomata F, et al. Hepatitis B prevalence in the Turkish population of Arnhem: implications for national screening policy? Epidemiol Infect. 2012;140(4):724-30.

39. Froom P, Melamed S, Kristal-Boneh E, Benbassat J, Ribak J. Healthy volunteer effect in industrial workers. J Clin Epidemiol. 1999;52(8):731-5.

40. Numans ME, Perquin MJ, van Putten AM, Richter C, Vrolijk JM, Bouma M. MS. Virushepatitis en andere leveraandoeningen, derde herziening. [Dutch College of General Practitioners Guideline "viral hepatitis and other liver conditions," third revision]. Huisarts Wet. 2016;3:108-19.

41. Beekmans N, Klemt-Kropp M. Re-evaluation of chronic hepatitis B and hepatitis C patients lost to follow-up: results of the northern Holland hepatitis retrieval project. Hepatol Med Policy. 2018;3(1):5

42. Spruijt AG, Wilting KR, Mithoe GD, Niessen WJM. Tracing patients with chronic viral hepatitis. Ned Tijdschr Geneeskd. 2016;160(0):D414

43. Wevers K, Puts G, Waegemaekers C, Hautvast J, Tostmann A. Detection and evaluation of chronic hepatitis $B$ and $C$ patients who were lost to medical follow up. Eur J Pub Health. 2017;27(Suppl 3):261.

44. Kracht PAM, Arends JE, van Erpecum KJ, Thijsen SFT, Vlaminckx BJM, Weersink $A J$, et al. REtrieval and cure of chronic hepatitis $C(R E A C H)$ : results of micro-elimination in the Utrecht province. Liver Int. 2018. https://doi.org/ 10.1111/liv.13959.

45. Drenth JPH, et al. Nationale registratie van hepatitis B en C http://regist2. virology-education.com/Presentations/2017/NHD2017/11_Drenth.pdf. Accessed 2 Apr 2018.

46. Zorgthermometer: Verzekerden in beeld 2017 [report in Dutch]. Zeist; 2017. https://www.vektis.n//uploads/Publicaties/Zorgthermometer/Verzekerden in beeld 2017.pdf. Accessed 2 Apr 2018.

47. HCV richtsnoer. http://www.hcvrichtsnoer.nl/. Accessed 2 Apr 2018.

48. van Sighem A, Smit C, Holman R, Gras L, Stolte I, Bezemer D, et al. Monitoring report 2012. Human immunodeficiency virus (HIV) infection in the Netherlands. Stichting HIV Monitoring. 2012; https://www.hiv-monitoring.nl/ files/1013/5365/4371/HIV_MReport2012_web.pdf. Accessed 2 Apr 2018.

49. Heil J, Hoebe CJPA, Cals JWL, ter Waarbeek HLG, van Loo IHM, DukersMuijrers NHTM. Detecting hepatitis B and C by combined public health and primary care birth cohort testing. Ann Fam Med. 2018;16(1):21-7.

50. Willemse SB, Razavi-Shearer D, Zuure FR, Veldhuijzen IK, Croes EA, van der Meer AJ, et al. The estimated future disease burden of hepatitis $C$ virus in the Netherlands with different treatment paradigms. Neth J Med. 2015;73(9):417-31.
51. Volk JE, Marcus JL, Phengrasamy T, Hare CB. Incident hepatitis C virus infections among users of HIV Preexposure prophylaxis in a clinical practice setting. Clin Infect Dis. 2015;60(11):1728-9.

52. Molina J-M, Capitant C, Spire B, Pialoux G, Cotte L, Charreau I, et al. Ondemand preexposure prophylaxis in men at high risk for HIV-1 infection. N Engl J Med. 2015;373(23):2237-46.

53. McCormack S, Dunn DT, Desai M, Dolling DI, Gafos M, Gilson R, et al. Preexposure prophylaxis to prevent the acquisition of HIV-1 infection (PROUD): effectiveness results from the pilot phase of a pragmatic open-label randomised trial. Lancet (London, England). 2016;387(10013):53-60.

54. Salazar-Vizcaya L, Kouyos RD, Fehr J, Braun D, Estill J, Bernasconi E, et al. On the potential of a short-term intensive intervention to interrupt $\mathrm{HCV}$ transmission in HIV-positive men who have sex with men: a mathematical modelling study. J Viral Hepat. 2018;25(1):10-8.

55. Martin NK, Thornton A, Hickman M, Sabin C, Nelson M, Cooke GS, et al. Can hepatitis $\mathrm{C}$ virus ( $\mathrm{HCV}$ ) direct-acting antiviral treatment as prevention reverse the HCV epidemic among men who have sex with men in the United Kingdom? Epidemiological and modeling insights. Clin Infect Dis. 2016;62(9):1072-80.

56. Hill AM, Khan A, Nath S, Simmons B. "Diagnostic Burn-out" for Hepatitis C: when will countries run out of diagnosed people to treat with DAAs? Hepatology. 2017;66(Supplement 1):522A

57. Hoornenborg E, Achterbergh RCA, Schim van der Loeff MF, Davidovich U, Hogewoning A, de Vries HJC, et al. MSM starting preexposure prophylaxis are at risk of hepatitis C virus infection. Clin Infect Dis. 2017;31(11):1603-10.

58. Koopsen J, van Steenbergen J, Richardus JH, Prins M, Op De Coul ELM, Croes EA, et al. Chronic hepatitis B and C in the Netherlands: prevalence in high-risk groups and the general population (submitted). 2018.

59. van de Laar MW, van Ooyen-Houben MMJ, Cruts AAN, Meijer RF, Croes EA, Ketelaars PM, van der P PM. Netherlands National Drug Monitor: NDM Annual Report 2016. Utrecht / Den Haag: Trimbos Instituut / Den Haag: WODC. 2016. https://assets.trimbos.nl/docs/3fdeab39-f34e-4aa0-97af5dbf111c05a0.pdf. Accessed 2 April 2018.

60. Custodial Institutions Agency Ministry of Health. This is the Custodial Instititions Agency (DJI). 2017. https://www.dji.nl/binaries/LR_103353_ ditisDJIEN_tcm41-121757.pdf. Accessed 2 April 2018.

61. Leemrijse CJ, Bongers $M$, Nielen $M$, Devillé $W$. Hepatits $C$ in penitentiary: a prevalence study [report in Dutch]. Nivel. 2010. https://www.nivel.nl/sites/ default/files/bestanden/Rapport-hepatitis-C-penitentiaire-inrichtingen.pdf. Accessed 2 April 2018

62. Schreuder I, Van der Sande M, Osterhaus A, Boucher C, Pinxt J, Hoebe C, et al. Prevalence of HIV, hepatitis B and C in institutionalized men in Sittard [report in Dutch]. 2010. RIVM Rapport 210502001. https://www.rivm.nl/ dsresource?objectid=5aed8fcd-1b2b-44bf-b610-8d80b21c2e18\&type= org\&disposition=inline. Accessed 2 April 2018.

63. Nefrovisie. Renine (Dutch registry of dialysis treatments for kidney patients). 2016. https://www.nefrovisie.nl/wpcontent/uploads/2018/03/RENINE-yearreport2016-web.pdf. Accessed 2 April 2018.

\section{Ready to submit your research? Choose BMC and benefit from:}

- fast, convenient online submission

- thorough peer review by experienced researchers in your field

- rapid publication on acceptance

- support for research data, including large and complex data types

- gold Open Access which fosters wider collaboration and increased citations

- maximum visibility for your research: over $100 \mathrm{M}$ website views per year

At $\mathrm{BMC}$, research is always in progress.

Learn more biomedcentral.com/submissions 